Daniel Boćkowski

\title{
POLSKA - ZSRR W XX WIEKU \\ - NOWOŚCI WYDAWNICZE \\ Z 2002 I PIERWSZEGO PÓŁROCZA 2003 ROKU (WYBÓR)
}

Po raz drugi przedstawiam czytelnikom wybór prac dotyczących stosunków polsko-radzieckich i polsko-rosyjskich w XX wieku, a także kwestii rosyjskich w ogóle, które ukazały się na przełomie 2002/2003 oraz w pierwszej połowie 2003 roku. Ujmuję także te prace, do których nie dotarłem wcześniej.

Dla ułatwienia zestawienie publikacji podzieliłem na poszczególne lata. Za punkt odniesienia przy dodawaniu książki do niniejszego spisu przyjąłem podaną przez wydawnictwo datę wydania, choć wiem, że nie zawsze jest to adekwatne do faktycznego czasu ukazania się danej pozycji. Wydawnictwo podaję dla ułatwienia nabycia ewentualnej pozycji - większość wydawnictw posiada już swoje księgarnie internetowe. Zdaję sobie sprawę, że prezentowany przegląd nie jest pełny, niemniej jednak opracowanie takie powinno pomóc wielu historykom w poszukiwaniach bibliograficznych.

\section{Rok 2002}

1. Joanna Strzelczyk, Ucieczka ze wschodu. Rosja w polskiej polityce 1989-1993, Oficyna Wydawnicza Rytm, Warszawa 2002, ss. 488. Książka składa się z pięciu części podzielonych według kryterium problemowo-chronologicznego; z zachowaniem jednak we wszystkich częściach schematu omawiania podobnych bloków tematycznych (sprawy wojskowe, gospodarcze, polityka zagraniczna). Część pierwsza pt. Dryfowanie obejmuje okres od powołania rządu Tadeusza Mazowieckiego w 1989 roku do oficjalnego 
zażądania przez Polskę wycofania wojsk radzieckich, które miało miejsce w roku 1990. Część druga, Zmiany, omawia okres od wizyty ministra Krzysztofa Skubiszewskiego w Rosji, na Ukrainie i Białorusi jesienią 1990 roku, kończy zaś z chwilą likwidacji Układu Warszawskiego i RWPG w sierpniu 1991 roku. Część trzecia, Próba, dotyczy okresu od puczu z sierpnia 1991 roku do rozpadu ZSRR w grudniu 1991 roku i uznania przez Polskę niepodległych państw powstałych na gruzach radzieckiego imperium. W części czwartej, Zderzenie, omówione zostały stosunki polsko-rosy jskie w pierwszej połowie 1992 roku, zakończone wizytą Lecha Wałęsy w Moskwie oraz upadkiem gabinetu Jan Olszewskiego. Część piąta, Ucieczka, dotyczy polityki zagranicznej Polski wobec Rosji w okresie od czerwca 1992 roku do września 1993 roku, ze szczególnym uwzględnieniem kwestii zgody Rosji co do wstąpienia Polski do NATO oraz wizyty w naszym kraju Borysa Jelcyna. Całość kończy - jak to określiła sama autorka - „kulminacyjny moment - wyjście z Polski rosyjskich wojsk po prawie pół wieku stałego stacjonowania". Praca oparta jest na obszernym materiale źródłowym (umowach międzypaństwowych, prasie, relacjach uczestników wydarzeń), którego wybór zamieszcza autorka w bibliografii. Pracę kończą indeksy: osobowy i miejscowości.

2. $\dot{Z} y d z i$ i stosunki polsko-żydowskie $w$ regionie tomżyńskim $w X I X$ i XX wieku. Studia i materiaty, pod red. Michała Gnatowskiego, Łomża, 2002, ss. 160. Praca stanowi podsumowanie konferencji naukowej odbytej w 2001 roku pt. Stosunki polsko-żydowskie $w$ regionie tomżyńskim $w X I X$ $i X X$ wieku. W jej trakcie podjęto próbę podsumowania stanu badań nad wymienioną problematyką. Złożyło się na nią 12 artykułów omawiających dzieje Żydów w regionie łomżyńskim w XIX i XX wieku, podzielonych na trzy części. W pierwszej, Stan badań i źródta, Siergiej Piwowarczyk z Grodna przedstawił informacje o materiałach do historii Żydów w archiwach Grodna - dotyczy to także losów polskich Żydów na Ziemi Łomżyńskiej wcielonej do ZSRR po 17 września 1939 roku, zaś Zbigniew Romaniuk nakreślił stosunki polsko-żydowskie w regionie w świetle wytworzonych przez żydowską diasporę „Ksiąg pamięci”. W części drugiej, Stosunki polsko-żydowskie, Jarosław Wołkonowski opisał rok $1931 \mathrm{w}$ stosunkach polsko-żydowskich w Wilnie, zaś autor niniejszej pracy losy polskich Żydów na zesłaniu w głębi ZSRR. W najobszerniejszej części trzeciej, Żydzi i stosunki polsko-żydowskie w regionie tomżyńskim, Michał Gnatowski pisze o przystosowanych i niepokornych Żydach i Polakach w regionie łomżyńskim w latach 1939-1941 w świetle radzieckich źródeł. Dla okresu wcześniejszego warte zauważenia są opracowania Leszka Koconia - poświęcone ludności żydowskiej w Łomżyńskiem w XIX i XX wieku, Małgorzaty Dajnowicz o życiu społeczności żydowskiej 
w zaściankach łomżyńskich na przełomie XIX i XX wieku oraz Janusza Gołoty o losach Żydów ostrołęckich od początków osadnictwa żydowskiego do zagłady.

3. Czesław Grzelak, Henryk Stańczyk, Stefan Zwoliński, Armia Berlinga i Żymierskiego, Wydawnictwo Neriton, Warszawa 2002, ss. 434. Książka stanowi próbę ponownego spojrzenia na kwestię wysiłku zbrojnego Wojska Polskiego na froncie wschodnim od chwili jego powstania do zakończenia działań wojennych w maju 1945 roku. Praca składa się z sześciu rozdziałów problemowych. W pierwszym autorzy skoncentrowali się na społeczno-politycznych aspektach formowania się polskich oddziałów w ZSRR (genezie formowania oddziałów, próbie narzucenia wojsku zwierzchnictwa przez polskich komunistów, problemach braterstwa broni, podporządkowaniu armii interesom PPR), na prowadzonej w armii polityce kadrowej na wszystkich szczeblach. Szczególnie cenne są opracowania dotyczące „działalności instytucji czuwających nad »czystością«i »prawomyślnością« polskich szeregów”. W kolejnych rozdziałach omówiono organizację armii i jej techniczne wyposażenie, kadrę oficerską i podoficerską (zarówno własną, jak i sojuszniczą), szkolenie bojowe żołnierzy, szlak bojowy Kościuszkowców od Lenino do Berlina ze szczególnym uwzględnieniem przemilczanych dotychczas zagadnień dotyczących błędów w dowodzeniu, bilans szlaku bojowego, rolę polskich żołnierzy w początkowej fazie okupacji terytorium Niemiec oraz zadania, jakie czekały na nich po powrocie do kraju. Pracę uzupełniaja liczne materiały źródłowe, szkice i ikonografia. Całość kończą indeksy: geograficzny i osobowy.

4. Andrzej Romanowski, Jak oszukać Rosję. Losy Polaków od XVIII do XX wieku, Wydawnictwo Znak, Kraków 2002, ss. 305. Książka stanowi zbiór 13 szkiców publikowanych wcześniej w "Tygodniku Powszechnym”, miesięczniku „Znak”, „Przeglądzie Katolickim”, „Gazecie Wyborczej” oraz podziemnej „Arce”. „Jak oszukać Rosję? - to pytanie przez wieki trapiło polskich władców, polityków i wojskowych. [...] Każde $z$ nich inaczej zmagało się z problemem Rosji, czyniąc to niekiedy w sposób zaskakujący, odbiegający od utrwalonego stereotypu". Książka Andrzeja Romanowskiego przez wielu czytelników odebrana zostanie podobnie. Autor w sposób zaskakujący, bardzo często $z$ dużą dozą przekory i w niebanalny sposób kreśli sylwetki największych Polaków i ich zmagania $z$ Rosją. Stara się obalać narosłe przez wieki mity i stereotypy. Na kartach książki znajdziemy m.in. eseje o Tadeuszu Kościuszce, Stanisławie Auguście Poniatowskim, Walerianie Łukasińskim, Józefie Piłsudskim, Nikodemie Suliku, Kazimierzu Sosnkowskim. Każda postać ukazana jest w sposób całkowicie odmienny od tego, w jaki 
postrzegana jest przez zbiorową pamięć historyczną, co nieraz zmusza czytelnika do przewartościowania swoich dotychczasowych sądów na - wydawałoby się - powszechnie znane postaci i wydarzenia historyczne. Praca wyposażona jest w noty bibliograficzne oraz obszerny indeks osobowy.

5. Richard Pipes, Rosja, komunizm i świat. Wybór esejów, Wydawnictwo Arkana, Kraków 2002, ss. 224. Zbiór 11 esejów zawarty w tej pracy przedstawia fascynująca historię myśli, która doprowadziła do obalenia systemu sowieckiego. To myśl o zagrożeniu, jakie tworzy ten system dla wolnego świata, o potrzebie i możliwościach skutecznego przeciwstawienia się temu zagrożeniu. Teksty publikowane przez Pipesa w. „Foreign Affairs”, "Commentary”, „Encounter” oraz "National Interest” prezentowały konsekwentnie tę myśl, do której kluczem była jego historyczna wiedza o Rosji i zarazem rozpoznanie istoty komunizmu. Jak pisze we wstępie, ,jako człowiekowi urodzonemu w państwie sąsiadującym z Rosją zostały mi oszczędzone romantyczne złudzenia na temat owego wielkiego kraju". Było to więc spojrzenie na Rosję bez złudzeń, a jednocześnie poprzez pryzmat wielkiej polityki, w której jako doradca Ronalda Reagana aktywnie uczestniczył. Dlatego też jego diagnozy okazały się bez porównania trafniejsze niż koncepcje całej „postępowej” sowietologii zachodniej. Jednak, jak sam zauważa, nie wszystkie okazały się trafne, m.in. niedocenienie siły rosyjskich nacjonalistów, czy też pragmatyzm Putina.

6. Józef Smaga, Rosja w 20 stuleciu, Wydawnictwo Znak, Kraków 2002, ss. 350. Praca stanowi zmienione i poszerzone wydanie książki Narodziny $i$ upadek imperium ZSRR 1917-1991 wydanej przez „Znak” w 1992 roku. Jest to, jak dotąd, druga na polskim rynku książka starająca się w sposób możliwie przystępny przybliżyć przeciętnemu czytelnikowi złożoną i nadal pełną pytań historię radzieckiego imperium od powstania w 1917 roku do upadku w 1991 oraz dzieje współczesnej Rosji. Praca składa się z dziewięciu części, w których autor zapoznaje czytelnika kolejno z przyczynami upadku imperium Romanowych oraz przebiegiem bolszewickiego puczu z listopada 1917 roku, okresem leninowskim, czasami dyktatury Stalina, postalinowską odwilżą, realnym socjalizmem doby Breżniewa, okresem przejściowym Andropowa i Czernienki, latami pierestrojki Gorbaczowa, okresem „panowania” Borysa Jelcyna (od rozpadu ZSRR do jego „abdykacji” w noc sylwestrową 1999 roku) oraz współczesnymi problemami Rosji putinowskiej. Opracowując historię ZSRR oraz współczesnej Rosji, autor w dużej mierze oparł się na aktualnych opracowaniach publikowanych w rosy jskich gazetach i czasopismach naukowych. Pracę kończy obszerny indeks osobowy, zabrakło - niestety - bibliografii, a szkoda, ułatwiłoby to bardzo pracę osobom 
chcącym pogłębić swoją wiedzę i pozwoliło dotrzeć do cytowanych przez autora prac historyków rosyjskich.

7. Marek Kornat, Polska szkota sowietologiczna, Wydawnictwo Arkana, Kraków 2002, ss. 623. Książka obejmuje wybór najważniejszych prac sowietologów polskich okresu międzywojennego, związanych z Instytutem $\mathrm{Na-}$ ukowo-Badawczym Europy Wschodniej w Wilnie (1930-1939). Teksty te poprzedza studium monograficzne o Instytucie Wileńskim. Praca składa się z czterech rozdziałów, w których przedstawiono pogląd polskich sowietologów okresu międzywojennego kolejno na: prawo i ustrój ZSRR, politykę gospodarczą, osobę Lenina oraz istotę bolszewizmu, a także przyszłość rozwoju badań sowietologicznych. W pracy zamieszczono publikacje Stanisława Swianiewicza, Aleksandra Bocheńskiego, Wiktora Sukiennickiego, Wacława Komarnickiego i Franciszka Ancewicza. Publikujac powstałe przed laty studia i artykuły polskich badaczy systemu sowieckiego autor pragnął przypomnieć całkowicie zapomnianą kartę $z$ dziejów polskiej myśli historycznej i prawniczej, gdyż - jak pisze we wstępie - „poglądy uczonych polskich formułowane w toczącym się w dobie międzywojennej sporze wokół systemów totalitarnych na takie przypomnienie $z$ pewnościa zasługują". Pracę kończą biogramy czołowych postaci związanych z Instytutem Naukowo-Badawczym Europy Wschodniej w Wilnie, bibliografia ważniejszych publikacji pracowników i badaczy Instytutu Wileńskiego, zestawienie prac o studiach sowietologicznych w Polsce międzywojennej oraz o Instytucie Naukowo-Badawczym Europy Wschodniej, a także spis wykładów i wykładowców pracujących w szkole Nauk Politycznych. Praca wyposażona jest w indeks osobowy.

8. Mirosław Boruta, Wolni z wolnymi, równi z równymi. Polska i Polacy o niepodlegtości wschodnich sasiadów Rzeczypospolitej, Wydawnictwo Arkana, Kraków 2002, ss. 355. „Głównym celem tej książki - pisze autor we Wstępie - jest przypomnienie dawnych i współczesnych poglądów politycznych tych polskich środowisk i tych jednostek, które dostrzegały we wschodnich sąsiadach pełnoprawnych partnerów, uznawały ich prawo do samodzielnego bytu narodowego i pragnęły współpracy z nimi na wspólnej drodze ku wolności". Praca składa się z siedmiu rozdziałów, w których autor omawia kolejne etapy i okoliczności, w jakich powstawała, kształtowała się, rozwijała i realizowała myśl polityczna i historyczna uznająca naszych wschodnich sąsiadów za równorzędnych partnerów. Opierając się na niezwykle obszernej bazie dokumentów, tekstów źródłowych oraz-opracowań wytwarzanych przez polskich historyków, polityków i politologów od okresu poprzedzającego wybuch I wojny światowej do czasów nam współczesnych, 
nakreśla praktycznie nieznany wielu badaczom tego tematu obraz dojrzewania „historycznej” odpowiedzialności Polski i Polaków za istnienie, rozwój i przetrwanie narodowych państw na wschód od „linii Curzona”. Praca zawiera bardzo obszerną bibliografię tematu oraz indeks osobowy.

9. Roman Szporluk, Imperium, komunizm i narody. Wybór esejów, Wydawnictwo Arkana, Kraków 2002, ss. 327. W swej pracy autor (profesor historii na Uniwersytecie Harvarda) stara się przybliżyć czytelnikom objawy dojrzewania antysowieckiego nacjonalizmu samych Rosjan. Zasadniczy konflikt polityczny w końcowej fazie ZSRR streścił we wciąż aktualnej formule sporu między rosyjskimi nation-builders (twórcami nowoczesnego narodu) a empire-savers (obrońcami imperium). Drugi istotny konflikt, jaki opisuje, to zderzenie struktur dominacji sowieckiego centrum nad imperialnymi peryferiami z dążeniami do usamodzielnienia innych, nierosyjskich narodów ZSRR, w szczególności Ukrainy. Profesor Harvardu przedstawia proces formowania narodu ukraińskiego w kontekście historii jego związków z Polską - jako wyzwaniem i jako modelem rozwoju. „Powstanie państw narodowych na post-sowieckiej przestrzeni bardziej ułatwiło narodom dawnego ZSRR uczestnictwo we wspólnych sprawach ludzkości, niż było to możliwe w »internacjonalistyczny $m$ « imperium sowieckim. [...] Nacjonalizm nie tylko podważa imperia intelektualnie, wspierając widzenie danego narodu w kontekście globalnym: głosi samookreślenie wspólnot, które są podporządkowane imperiom i cywilizacjom - w imię uniwersalnych zasad" - to cytat z ostatniego eseju tej książki. Kolejne eseje-rozdziały pracy dotyczą: powstania teorii i praktyki nowoczesnego narodu polskiego, stosunków polsko-ukraińskich w 1918 roku, losów Ukrainy od imperialnej peryferii do suwerennego państwa, dylematów rosyjskiego nacjonalizmu w obliczu nowej w treści i formie konstrukcji pańšwa, rosyjskiego problemu narodowościowego w obliczu klęski idei „narodu sowieckiego", problemów z samookreśleniem przez Rosjan tlących się w nich nadal idei imperialnych oraz próby odpowiedzenia na pytanie: dlaczego upadło imperium sowieckie? W ostatnim rozdziale autor próbuje też nakreślić obraz Europy Środkowej i Wschodniej po upadku komunizmu i odrodzeniu się nacjonalizmów w Rosji, Polsce, na Ukrainie i Białorusi.

\section{Rok 2003}

1. Michał Gnatowski, „Sasiedzi” w sowieckim raju. Rejon jedwabieński pod radzieckq wtadza 1939-19 1, Łomżyńskie Towarzystwo Naukowe im. Wagów, Łomża 2003, ss. 302. Praca stanowi plon ostatnich kwerend 
archiwalnych autora prowadzonych m.in. w Państwowym Archiwum Organizacji Społecznych Obwodu Grodzieńskiego w Grodnie, Narodowym Archiwum Republiki Białorusi w Mińsku, Archiwum Akt Nowych w Warszawie, Archiwum Wschodnim Ośrodka Karta w Warszawie oraz Archiwum Zakładu Historii Ruchu Ludowego. Książka składa się z dwóch części: monograficznego opracowania dziejów powołanego w styczniu 1940 roku rejonu jedwabieńskiego oraz dokumentów (w przekładzie autora) wytworzonych m.in. przez Komitet Rejonowy KP(b)B w Jedwabnem, Rejonowy Wydział NKWD w Jedwabnem, naczelnika Zarządu Obwodowego NKWD w Białymstoku oraz Ludowy Komisariat Spraw Wewnętrznych BSRR w Mińsku. Część pierwsza, określona jako Studia, podzielona została na 5 rozdziałów. W rozdziale pierwszym M. Gnatowski przybliża czytelnikowi radziecką agresję 17 września 1939 roku oraz okoliczności, w jakich nastąpiło zajęcie ziem regionu łomżyńskiego przez Armię Czerwoną. Rozdział drugi dotyczy powstania rejonu jedwabieńskiego oraz jego charakterystyki społeczno-gospodarczej i politycznej. W rozdziale trzecim autor omawia kolejno: komisaryczne władze regionu działające od stycznia do grudnia 1940 roku, przygotowania i kampanię wyborczą do władz terenowych oraz skład i zadania stojące przed nowymi władzami rejonowymi. Bardzo ważny jest rozdział czwarty, w którym pokazana została „urzędowa sowietyzacja i rusyfikacja rejonu". W ostatnim rozdziale części pierwszej M. Gnatowski szczegółowo omawia opór społeczny oraz działalność polskiego podziemia niepodległościowego w rejonie jedwabieńskim. W części drugiej znalazło się 29 przełożonych na jęz. polski dokumentów, dotyczących m.in. propozycji podziału administracyjnego rejon $u, k$ westii nauczania radzieckiego aktywu partyjnego języka polskiego, sytuacji społeczno-politycznej w rejonie w okresie władzy radzieckiej oraz działalności polskiego podziemia niepodległościowego. Pracę kończy bibliografia oraz sześć aneksów zawierających m.in. imienne zestawienia obsady kadrowej radzieckich władz terenowych w rejonie jedwabieńskim oraz wykaz pracowników skierowanych do rejonu ze wschodnich obwodów ZSRR i BSRR. Niestety, w pracy brakuje indeksów.

2. Lech Wyszczelski, peracja niemeńska 1920 roku, Wydawnictwo Neriton, Warszawa 2003, ss. 467. Praca, oparta w dużej mierze na archiwaliach zgromadzonych w AAN, CAW i Ośrodku Przechowywania Zbiorów Historyczno-Dokumentalnych w Moskwie, dotyczy najważniejszej, po bitwie na przedpolach Warszawy, operacji militarnej przeprowadzonej przez wojska II RP w czasie konfliktu zbrojnego z Rosją Radziecką. Rozbicie wojsk Frontu Zachodniego dowodzonych przez Michaiła Tuchaczewskiego przesądziło nie tylko o losach wojny, ale także o ostatecznym kształcie polskiej 
granicy wschodniej, a także losach Wileńszczyzny. W kolejnych rozdziałach autor omawia sytuację na froncie po odparciu pod Warszawą bolszewickiego natarcia, plany Tuchaczewskiego (pobitego, ale nie pokonanego), przygotowania do wydania oddziałom Frontu Północno-Zachodniego decydującej bitwy, mającej ostatecznie przesądzić o całej kampanii 1920 roku, a następnie przebieg całej operacji niemeńskiej - od fazy wstępnej (20-23 września), przez walki 2. Armii pod Grodnem i 4. Armii pod Wołkowyskiem (24-25 września), próby okrążenia rosyjskiej 3.. i 15. Armii (26-28 września), a także pościg za wycofującym się bezładnie przeciwnikiem (29 września - 3 października). W ostatniej części pracy przedstawiono okoliczności i przebieg marszu generała Żeligowskiego na Wilno, a następnie rokowania pokojowe zakończone podpisaniem traktatu ryskiego. Pracę kończy obszerna bibliografia tematu, streszczenia w języku rosyjskim i angielskim, indeksy: osobowy i nazw geograficznych, oraz 36 fotografii.

3. Dariusz Matelski, Losy polskich dóbr kultury w Rosji i ZSRR. Próby restytucji. Archiwa - Księgozbiory - Dzieta sztuki - Pomniki, Poznań 2003, ss. 310. Praca składa się z sześciu rozdziałów. Pierwszy dotyczy strat polskich dóbr kultury w okresie Rzeczypospolitej Obojga Narodów (do 1795 roku). W rozdziale drugim przedstawiono losy polskich dóbr kultury w okresie rozbiorów (do 1918 roku). Rozdział trzeci dotyczy starań restytucyjnych prowadzonych przez władze II Rzeczypospolitej w okresie międzywojennym. Rozdział czwarty ukazuje straty poniesione przez Polskę w okresie II wojny światowej w wyniku rabunkowej polityki władz radzieckich - zarówno w okresie okupacji radzieckiej 1939-1941, jak i po zajęciu ziem polskich w 1944 roku, w wyniku działań powołanych specjalnie w celu rabunku dzieł sztuki grup operacyjnych składających się z dyrektorów najważniejszych radzieckich placówek muzealnych. Omówione w nim zostały także powojenne zabiegi władz Polski mające na celu ich odzyskanie. Rozdział piąty obejmuje starania władz PRL-u i Trzeciej Rzeczypospolitej oraz polskich instytucji archiwalnych i kulturalnych, zmierzające do odzyskania dóbr kultury wywiezionych zarówno przez Niemców, jak i Rosjan w okresie okupacji, rewindykację i reewakuację ze stref okupowanych Niemiec i Austrii, a także repatriację i rewindykację polskich dóbr kultury znajdujących się na terenie ZSRR (do 1991 roku). Rozdział szósty dotyczy rokowań prowadzonych przez władze polskie odnośnie zwrotu polskich dóbr kultury znajdujących się w posiadaniu państw powstałych po rozpadzie ZSRR (Ukrainy, Białorusi, Litwy i Rosji). Oddzielnie autor omawia też losy dóbr kultury innych państw, które w wyniku działań wojennych znalazły się na obszarze Polski (i są obecnie w posiadaniu polskich placówek muzealnych), a których 
zwrotu domagają się lub mogą się domagać państwa ościenne. Badacz zastanawia się także nad szansą powodzenia polskich planów restytucyjnych W zakończeniu pracy autor raz jeszcze sumuje straty Polski powstałe w wyniku grabieży prowadzonych przez Rosję i ZSRR od XVIII wieku, a także kreśli prawno-międzynarodowe uwarunkowania przy podejmowaniu przez naś kraj negocjacji restytucyjnych z sąsiadami. Książkę kończy aneks zawierający fragmenty traktatów międzynarodowych (dotyczących dóbr kultury) zawartych przez II RP i polskie władze powojenne (do 1994 roku) ze wschodnimi sąsiadami Polski, obszerna bibliografia tematu, a także indeks osobowy i streszczenie w języku niemieckim. 